This document is the accepted manuscript version of the following article:

Harris, E., Zeyer, K., Kegel, R., Müller, B., Emmenegger, L., \& Mohn, J. (2015). Nitrous oxide and methane emissions and nitrous oxide isotopic composition from waste incineration in Switzerland. Waste Management, 35(11), 135-140. https://doi.org/10.1016/ j.wasman. 2014.10.016

This manuscript version is made available under the CC-BY-NC-ND 4.0 1icense http://creativecommons.org/1icenses/by-nc-nd/4.0/

\title{
Nitrous oxide and methane emissions and nitrous oxide isotopic composition from waste incineration in Switzerland
}

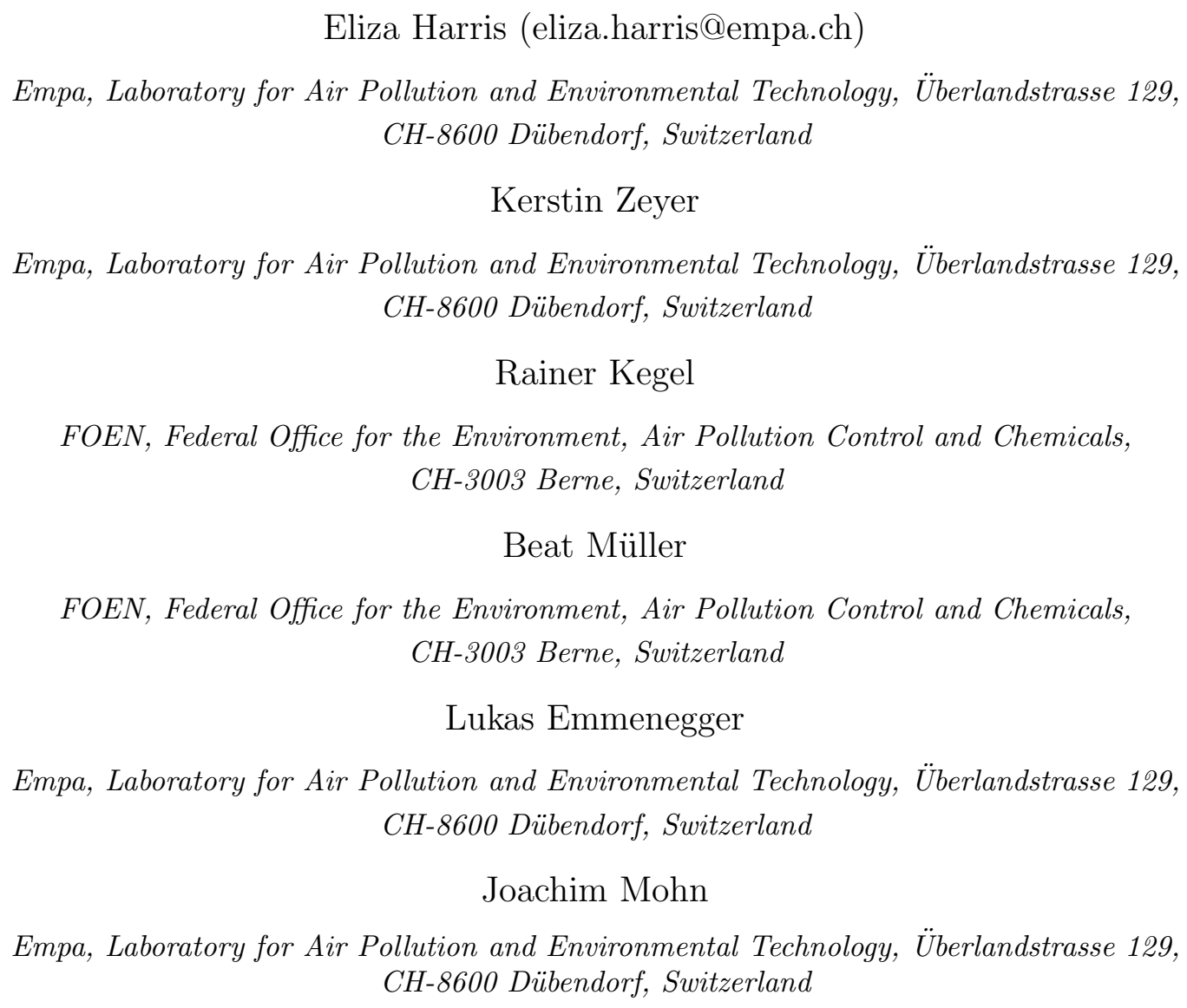


were determined based on measurements of representative flue gas samples, which were collected in Tedlar bags over a one year period (September 2010 - August 2011) and analysed with FTIR spectroscopy. All five plants burn a mixture of household and industrial waste, and two of the plants employ $\mathrm{NO}_{\mathrm{x}}$ removal through selective non-catalytic reduction (SNCR) while three plants use selective catalytic reduction (SCR) for $\mathrm{NO}_{\mathrm{x}}$ removal.

$\mathrm{N}_{2} \mathrm{O}$ emissions from incineration plants with $\mathrm{NO}_{\mathrm{x}}$ removal through selective catalytic reduction were $4.3 \pm 4.0 \mathrm{~g} \mathrm{~N}_{2} \mathrm{O}$ tonne ${ }^{-1}$ waste (wet) (hereafter abbreviated as $\left.\mathrm{t}^{-1}\right)\left(0.4 \pm 0.4 \mathrm{~g} \mathrm{~N}_{2} \mathrm{O} \mathrm{GJ}^{-1}\right)$, ten times lower than from plants with selective non-catalytic reduction $\left(51.5 \pm 10.6 \mathrm{~g} \mathrm{~N}_{2} \mathrm{O} \mathrm{t}{ }^{-1} ; 4.5 \pm 0.9 \mathrm{~g} \mathrm{~N}_{2} \mathrm{O}\right.$ $\mathrm{GJ}^{-1}$ ). These emission factors, which are much lower than the value of $120 \mathrm{~g}$ $\mathrm{N}_{2} \mathrm{O} \mathrm{t}^{-1}$ (10.4 $\mathrm{g} \mathrm{N}_{2} \mathrm{O} \mathrm{GJ}^{-1}$ ) used in the 2013 Swiss national greenhouse gas emission inventory, have been implemented in the most recent Swiss emission inventory. In addition, the isotopic composition of $\mathrm{N}_{2} \mathrm{O}$ emitted from the two plants with SNCR, which had considerable $\mathrm{N}_{2} \mathrm{O}$ emissions, was measured using quantum cascade laser spectroscopy. The isotopic site preference of $\mathrm{N}_{2} \mathrm{O}$ - the enrichment of ${ }^{14} \mathrm{~N}^{15} \mathrm{NO}$ relative to ${ }^{15} \mathrm{~N}^{14} \mathrm{NO}$ - was found to be $17.6 \pm 0.8 \%$, with no significant difference between the two plants. Comparison to previous studies suggests SP of $17-19 \%$ may be characteristic for $\mathrm{N}_{2} \mathrm{O}$ produced from SNCR. Methane emissions were found to be insignificant, with a maximum emission factor of $2.5 \pm 5.6 \mathrm{~g} \mathrm{CH}_{4} \mathrm{t}^{-1}\left(0.2 \pm 0.5 \mathrm{~g} \mathrm{CH}_{4}\right.$ GJ $J^{-1}$, which is expected due to high incinerator temperatures and efficient combustion.

\section{Keywords: Waste incineration, Nitrous oxide, Emission factors, deNO} technology, Greenhouse gas, Isotopic composition

\section{Highlights}

- $\mathrm{N}_{2} \mathrm{O}$ emissions from waste incineration with $\mathrm{SNCR}$ for $\mathrm{NO}_{\mathrm{x}}$ removal are $51.5 \pm 10.6 \mathrm{~g} \mathrm{~N}_{2} \mathrm{O} \mathrm{t}^{-1}$ waste (wet), 10 times higher than with SCR $\left(4.3 \pm 4.0 \mathrm{~g} \mathrm{~N}_{2} \mathrm{O} \mathrm{t}^{-1}\right)$ but significantly lower than the reported Swiss emission factor of $120 \mathrm{~g} \mathrm{~N}_{2} \mathrm{O} \mathrm{t}^{-1}$ (FOEN, 2013)

- $\mathrm{N}_{2} \mathrm{O}$ accounts for $<0.3 \%$ of GHG emissions from plants with SCR and $\approx 2.5 \%$ of GHG emissions from plants with SNCR

- Measured isotopic SP of $\mathrm{N}_{2} \mathrm{O}$ from SNCR plants $(17.7 \pm 0.6 \%$ ) is likely characteristic for $\mathrm{N}_{2} \mathrm{O}$ emissions from SNCR 
- $\mathrm{CH}_{4}$ emissions from waste incineration are negligible, contributing $<0.01 \%$ of GHG emissions

\section{Introduction}

Incineration of municipal solid waste (MSW) and solid recovered fuels (SRF) in waste-to-energy (WTE) plants is the most important waste disposal method employed in Switzerland, accounting for the disposal of $>3.7$ million tonnes of waste in 29 WTE plants annually (FOEN, 2014). The use of waste incineration as a waste disposal method is increasing worldwide due to concerns about the space requirements and the potential for soil and water pollution associated with landfilling, and because of the added benefit of energy recovery from incineration (Astrup et al., 2009; Hoornweg and BhadaTata, 2012). In Europe, approximately $22 \%$ of waste is currently incinerated; this amount is increasing due to the EU Landfill Directive (Bogner et al., 2007, 2008).

Significant amounts of $\mathrm{CO}_{2}$ and $\mathrm{N}_{2} \mathrm{O}$ are emitted during waste incineration, as well as minor amounts of $\mathrm{CH}_{4}$. Emissions of these important greenhouse gases (GHGs) must be reported under the United Nations Framework Convention of Climate Change (UNFCCC; UN (1992)). Although WTE is not a key category for GHG emissions, its increasing use in both developed and developing nations makes monitoring of emissions important (Bogner et al., 2008). Tier III reporting is good practice for WTE emissions, which requires the use of plant- and management-specific emission factors (IPCC, 2006).

The type of incineration facility (eg. stoker or fluidized bed), waste type (e.g. sewage sludge or MSW) and flue gas cleaning all have a significant impact on greenhouse gas emissions. This study focuses on flue gas cleaning technologies, as the other factors are very similar throughout all WTE plants in Switzerland. $\mathrm{NO}_{\mathrm{x}}$ removal is important for air quality and a wide range of environmental issues, such as photochemical smog, acid rain, and tropospheric ozone formation (Skalska et al., 2010). However, $\mathrm{NO}_{\mathrm{x}}$ removal can result in the conversion of a significant amount of $\mathrm{NO}_{\mathrm{x}}$ to $\mathrm{N}_{2} \mathrm{O}$. The most common $\mathrm{NO}_{\mathrm{x}}$ abatement methods are selective non-catalytic and selective catalytic reduction (SNCR and SCR, respectively).

SNCR involves the reduction of $\mathrm{NO}_{\mathrm{x}}$ by a reducing agent such as ammonia (Zandaryaa et al., 2001; Svoboda et al., 2006). It is advantageous due to 
simplicity, retrofittability, and low operating costs. However, the $\mathrm{NO}_{\mathrm{x}}$ reduction efficiency with SNCR is limited to $60-90 \%$. Under optimal conditions with ammonia as a reducing agent, $\mathrm{NO}_{\mathrm{x}}$ to $\mathrm{N}_{2} \mathrm{O}$ conversion can be as low as $2 \%$, however with urea or cyanuric acid as a reducing agent $\mathrm{NO}_{\mathrm{x}}$ to $\mathrm{N}_{2} \mathrm{O}$ is $>10 \%$ (Svoboda et al., 2006; Grosso et al., 2009).

$\mathrm{NO}_{\mathrm{x}}$ removal with SCR achieves a more efficient reduction of $\mathrm{NO}_{\mathrm{x}}$, on the order of $80-90 \%$, using a catalyst operated at $200-350^{\circ} \mathrm{C}$. The three major types of catalysts are currently: i) supported noble metal catalysts eg. $\mathrm{Pt} / \mathrm{Al}_{2} \mathrm{O}_{3}$, ii) base metal oxide catalysis eg. those containing vanadium, such as $\mathrm{TiO}_{2}-\mathrm{V}_{2} \mathrm{O}_{5}-\mathrm{WO}_{3}$, and iii) metal ion exchanged zeolites-crystalline silicate eg. Cu-ZSM-5 (Skalska et al., 2010). Recently, base metal-oxide catalysts are being replaced by the more modern zeolite catalysis. $\mathrm{N}_{2} \mathrm{O}$ emissions from SCR are typically $<1 \%$ of reduced $\mathrm{NO}_{\mathrm{x}}$, however, the use of a catalyst makes operation more expensive and complicated (Skalska et al., 2010). $\mathrm{N}_{2} \mathrm{O}$ emissions can increase due to catalyst aging, process temperature and water vapour concentration (Svoboda et al., 2006).

In addition to direct emissions of $\mathrm{N}_{2} \mathrm{O}$ and $\mathrm{CO}_{2}$, the energy balance and the environmental and climatic impact of WTE in waste-to-energy plants is strongly affected by various upstream and downstream factors. The diversion of waste from landfilling provides a GHG benefit by reducing $\mathrm{CH}_{4}$ emissions, which accounts for the majority of GHG emissions from the waste sector (eg. 67\% in Korea, 49\% in Taiwan - Bogner et al. (2007); Park et al. (2011a); Fukushima et al. (2008)). Energy generation from waste incineration in WTE plants also provides a major GHG benefit (Fukushima et al., 2008). Ammonia slip (loss of ammonia) from $\mathrm{NO}_{\mathrm{x}}$ reduction can result in significant downstream GHG emissions following waste incineration, which can be more detrimental than the $\mathrm{NO}_{\mathrm{x}}$ being removed if the process is not operated efficiently (Moller et al., 2011). High $\mathrm{NO}_{\mathrm{x}}$ removal efficiency in SNCR operations requires high ammonia: $\mathrm{NO}_{\mathrm{x}}$ ratios, resulting in lower ammonia use efficiency and potentially higher ammonia slip - thus waste gas is usually washed with scrubbers (Zandaryaa et al., 2001; Moller et al., 2011).

Emission factors can be used to make a 'bottom-up' estimate of $\mathrm{N}_{2} \mathrm{O}$ source contributions. Monitoring of isotopic composition provides an independent means to characterize sources through atmospheric measurements to compare with bottom-up estimates (Mohn et al., 2010, 2012b; Toyoda et al., 2011; Harris et al., 2014). $\mathrm{N}_{2} \mathrm{O}$ has four major isotopocules: ${ }^{14} \mathrm{~N}^{14} \mathrm{~N}^{16} \mathrm{O}$, ${ }^{14} \mathrm{~N}^{15} \mathrm{~N}^{16} \mathrm{O}\left(\delta^{15} \mathrm{~N}^{\alpha}\right),{ }^{15} \mathrm{~N}^{14} \mathrm{~N}^{16} \mathrm{O}\left(\delta^{15} \mathrm{~N}^{\beta}\right)$, and ${ }^{14} \mathrm{~N}^{14} \mathrm{~N}^{18} \mathrm{O}$; the oxygen isotopic composition was not measured in this study, therefore only the first three 
isotopocules are considered. 'Site preference' (SP) refers to the difference in ${ }^{15} \mathrm{~N}$ isotopic composition of the central $(\alpha)$ position $\mathrm{N}$ compared to the terminal $(\beta)$ position $\mathrm{N}$ :

$$
\mathrm{SP}=\delta^{15} \mathrm{~N}^{\alpha}-\delta^{15} \mathrm{~N}^{\beta}
$$

Site preference, unlike $\delta^{15} \mathrm{~N}$, is independent of the isotopic composition of the reactant forming $\mathrm{N}_{2} \mathrm{O}$, and is therefore particularly useful to trace reactions and sources (Park et al., 2011b).

This study presents measurements of greenhouse gas $\left(\mathrm{N}_{2} \mathrm{O}, \mathrm{CH}_{4}\right.$ and $\left.\mathrm{CO}_{2}\right)$ mixing ratios in flue gas from five Swiss waste incineration plants with grate firing. $\mathrm{N}_{2} \mathrm{O}$ and $\mathrm{CH}_{4}$ emission factors are calculated and compared to expectations based on $\mathrm{NO}_{\mathrm{x}}$ removal technologies and IPCC recommendations. In addition, the isotopic composition of the $\mathrm{N}_{2} \mathrm{O}$ in flue gas is presented as a tool to disentangle sources and processes.

\section{Materials and Methods}

\subsection{Sample collection}

Representative flue gas samples were collected from five Swiss WTE facilities, labelled A-E, over week-long periods between September 2010 and August 2011 (Table 1). At plants A, C and E, 16 - 21 flue gas samples were collected, and at plants B and D, 7 - 9 samples. Facilities A-C employ $\mathrm{NO}_{\mathrm{x}}$ abatement with SCR while facilities D-E employ SNCR for $\mathrm{NO}_{\mathrm{x}}$ reduction. All incinerators are continuously operated underfeed stoker-type, burning solid recovered fuels without addition of sewage sludge. The shares of household and industrial waste are given in (Mohn et al., 2012a). The facilities burn between 92,000 and 233,000 tonnes of waste per year (BAFU, 2012).

Samples were collected in $44 \mathrm{~L}$ aluminium-lined gas bags (Ritter $\mathrm{GmbH}$,

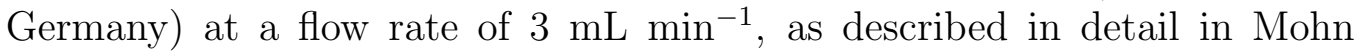
et al. (2012a). Most samples were collected for an entire week, except for the 4-5 July 2011 sample at plant E, which was collected over just two days. One sample each from plants A and D was not used due to interruptions in plant operation, and one sample from plant $\mathrm{E}$ was not used due to a power outage within the sampling setup. The bag sampling method was validated and found to produce equivalent results for $\mathrm{N}_{2} \mathrm{O}$ and $\mathrm{CH}_{4}$ mixing ratios compared to standard monitoring procedures (Zeyer and Mohn, 2013; VDI, 2005, 2008). 


\subsection{FTIR analysis}

The mixing ratios of $\mathrm{N}_{2} \mathrm{O}, \mathrm{CH}_{4}$ and $\mathrm{CO}_{2}$ in the bag samples were measured with a Nicolet Avatar 370 MCT FTIR spectrometer (Thermo Fisher Scientific Inc., USA) using a $50 \mathrm{~mL}$ heated $\left(40^{\circ} \mathrm{C}\right)$ flow-through gas cell with a $1 \mathrm{~m}$ pathlength (LFT-210, Axiom Analytical Inc., USA), as described in Mohn et al. (2012a). Quantitative results were obtained based on a Classical Least Square algorithm (TQ Analyst, Thermo Fisher Scientific, Inc.). Calibration spectra for $\mathrm{CO}_{2}, \mathrm{~N}_{2} \mathrm{O}$ and $\mathrm{CH}_{4}$ as well as interferent spectra for $\mathrm{CO}$ and $\mathrm{H}_{2} \mathrm{O}$ were obtained over the relevant mixing ratio range for the bag samples.

The uncertainty and limit of detection were estimated by comparing the absorption area of the reference spectra with the residuals of the acquired spectra over the relevant wavelength region for each component, according to NIOSH (2000). The limit of detection (LOD) for both $\mathrm{CH}_{4}$ and $\mathrm{N}_{2} \mathrm{O}$ is 0.3 ppm. Samples with a mixing ratio lower than the LOD are set to the LOD when calculating averages, thus reported values are a 'worst case' scenario. The measurement uncertainty for $\mathrm{CH}_{4}$ and $\mathrm{N}_{2} \mathrm{O}$ is $10 \%$ of the measured mixing ratio, minimum $0.3 \mathrm{ppm}$.

\subsection{Calculation of emission factors}

The $\mathrm{N}_{2} \mathrm{O}$ emission factors (EF) were estimated for each plant based on the ratio of $\mathrm{N}_{2} \mathrm{O}$ to $\mathrm{CO}_{2}$ in the flue gas, considering a $\mathrm{CO}_{2}$ emission factor of $1271 \mathrm{~kg} \mathrm{CO}_{2} \mathrm{t}^{-1}$ (EMIS, 2013):

$$
\mathrm{EF}_{\mathrm{N}_{2} \mathrm{O}}=\frac{\left[\mathrm{N}_{2} \mathrm{O}\right]}{\left[\mathrm{CO}_{2}\right]} \times \frac{\mathrm{MW}_{\mathrm{N}_{2} \mathrm{O}}}{\mathrm{MW}_{\mathrm{CO}_{2}}} \times 1271 \times 1000
$$

where EF is the emission factor for $\mathrm{N}_{2} \mathrm{O},\left[\mathrm{N}_{2} \mathrm{O}\right]$ and $\left[\mathrm{CO}_{2}\right]$ are the concentrations of $\mathrm{CO}_{2}$ and $\mathrm{N}_{2} \mathrm{O}$ measured in the flue gas, and $\mathrm{MW}$ is the molecular weight. The methane emission factors were calculated analogously. This approach is different from IPCC Tier 3, where emission factors are calculated based on emission concentrations, the amount of combusted waste and the flue gas volume by amount of incinerated waste IPCC (2006). Differences between plants in $\mathrm{CO}_{2}$ emission factors are however expected to be considerably smaller $( \pm 10-15 \%)$ than in $\mathrm{N}_{2} \mathrm{O}$ emission concentrations, even for plants with similar deNO $\mathrm{N}_{\mathrm{x}}$ technology.

The emission factors were calculated as $\mathrm{g} \mathrm{N}_{2} \mathrm{O} \mathrm{t}^{-1}$ to facilitate comparison with values in climate change assessment reports from other countries 
(Table 2). In the Swiss emission report, emission factors are reported under UNFCCC source category 1A1 (Energy Industries) as waste is burnt solely in WTE plants, therefore the EFs calculated in this study are also reported in $\mathrm{g}$ $\mathrm{N}_{2} \mathrm{O} \mathrm{GJ}^{-1}$ using an energy capacity for 2012 of $0.0115 \mathrm{TJ} \mathrm{t}^{-1}$ for consistency with these reports (BFE/BAFU, 2013). To calculate an average Swiss EF, the proportion of waste that is burnt in WTE facilities with SCR compared to SNCR was taken into account. The mass of waste burnt in each of the 29 WTE plants in Switzerland in 2012 was taken from BAFU (2012) and the flue gas deNO $\mathrm{x}_{\mathrm{x}}$ technologies employed at each plant from BAFU (2004).

\subsection{Isotopic analysis of $\mathrm{N}_{2} \mathrm{O}$}

The $\mathrm{N}_{2} \mathrm{O}$ isotopic composition in six of the bag samples, indicated with stars in Figure 1, was measured using quantum cascade laser absorption spectroscopy (QCLAS, Wächter et al. (2008)). The $\mathrm{N}_{2} \mathrm{O}$ mixing ratio was too low for the samples to be analysed directly, therefore they were preconcentrated prior to analysis, as performed in a number of recent environmental studies (Mohn et al., 2010, 2012b; Köster et al., 2013; Harris et al., 2014). The samples were first dynamically diluted to approximately ambient mixing ratios (1:10 dilution to $\approx 290 \mathrm{ppb}$ ) with high purity synthetic air (Messer Schweiz AG, Switzerland) using two mass flow controllers (Vögtlin Instruments, Switzerland). A pump (KNF Neuberger, Switzerland) and a pressure relief valve was used to bring the diluted sample to 4 bar. Water was removed with a permeation dryer (PermaPure Inc., USA) and $\mathrm{CO}_{2}$ was chemically trapped with Ascarite (20 g, 10-35 mesh; Fluka Analytical Co., Switzerland) flanked by magnesium perchlorate $(2 \times 10 \mathrm{~g}$; Fluka Analytical Co., Switzerland). The sample was passed through a stainless steel filter (2 $\mu \mathrm{m}$ pore size; Swagelok Co., USA) and directed to the preconcentration unit. Preconcentration and isotopic analysis are described in detail in Mohn et al. (2012b); only significant changes will be mentioned here.

Preconcentration was carried out at a flow rate of $333 \mathrm{~mL} \mathrm{~min}^{-1}$ for $\approx 22$ minutes to achieve a total sample size of $\approx 7.3 \mathrm{~L}$, compared to $500 \mathrm{~mL} \mathrm{~min}^{-1}$ for 20 minutes with a $10 \mathrm{~L}$ sample size under standard operation. The $\mathrm{N}_{2} \mathrm{O}$ mixing ratio in the laser cell following preconcentration was $48 \mathrm{ppm}$, compared to $71 \mathrm{ppm}$ under standard operation in Mohn et al. (2012b). Corrections were applied for fractionation during preconcentration and for concentration dependence due to differences in mixing ratios between samples and standards. Two secondary calibration gases were diluted to approximately 
the sample mixing ratio with high purity synthetic air, to calibrate the measurements to the international isotopic standard scale, 'Air $\mathrm{N}_{2}$ '. The isotopic composition of these standards is known from measurement against in-house primary standards which have been analysed by S. Toyoda at the Tokyo Institute of Technology (Toyoda and Yoshida, 1999). The isotopic composition of the two standards are: 1) $\delta^{15} \mathrm{~N}^{\alpha}=2.1 \pm 0.1 \% 0, \delta^{15} \mathrm{~N}^{\beta}=2.0 \pm 0.2 \%$, $\left[\mathrm{N}_{2} \mathrm{O}\right]=$ $246.9 \pm 0.1 \mathrm{ppm}$; and 2) $\delta^{15} \mathrm{~N}^{\alpha}=25.0 \pm 0.1 \%$ o, $\delta^{15} \mathrm{~N}^{\beta}=24.8 \pm 0.2 \%$, $\left[\mathrm{N}_{2} \mathrm{O}\right]=$ $249.1 \pm 0.1 \mathrm{ppm}$. Compatibility of $\mathrm{N}_{2} \mathrm{O}$ isotopomer analysis by QCLAS with isotope ratio mass spectrometry (IRMS) laboratories was recently demonstrated in an interlaboratory comparison campaign (Mohn et al., 2014).

\section{Results and Discussion}

\section{1. $\mathrm{N}_{2} \mathrm{O}$ emissions}

The flue gas $\mathrm{N}_{2} \mathrm{O}$ mixing ratios in the one-week bag samples are shown in Figure 1 and the mean mixing ratios from each plant in Table 1. The $\mathrm{N}_{2} \mathrm{O}$ mixing ratios in the flue gas from plants with SCR $\mathrm{NO}_{\mathrm{x}}$ abatement are very close to the detection limit $(0.3 \mathrm{ppm})$ for almost all samples while the SNCR plants show significantly higher $\mathrm{N}_{2} \mathrm{O}$ mixing ratios, between 3 and 6 ppm $(\mathrm{p}<0.001)$. As all plants are continuously operated underfeed stokers burning solid recovered fuels, $\mathrm{N}_{2} \mathrm{O}$ emissions seem to be primarily determined by the deNO $\mathrm{x}_{\mathrm{x}}$ technology. The $\mathrm{N}_{2} \mathrm{O}$ mixing ratios measured at plant $\mathrm{E}$ are significantly higher than at plant $\mathrm{D}(\mathrm{p}<0.001)$, which is most likely due to less optimal SNCR conditions resulting in a higher conversion of $\mathrm{NO}_{\mathrm{x}}$ to $\mathrm{N}_{2} \mathrm{O}$.

The $\mathrm{N}_{2} \mathrm{O}$ emission factor for each plant was estimated from the ratio of $\mathrm{N}_{2} \mathrm{O}$ to $\mathrm{CO}_{2}$ in the flue gas considering a $\mathrm{CO}_{2}$ emission factor of $1271 \mathrm{~kg} \mathrm{CO}_{2}$ $\mathrm{t}^{-1}$ following Eq. 2 (EMIS, 2013). The mean $\mathrm{N}_{2} \mathrm{O}$ emission factor for SCR plants is $4.3 \pm 4.0 \mathrm{~g} \mathrm{~N}_{2} \mathrm{O} \mathrm{t}^{-1}\left(0.4 \pm 0.4 \mathrm{~g} \mathrm{~N}_{2} \mathrm{O} \mathrm{GJ}^{-1}\right)$, while for SNCR plants the emission factor is more than an order of magnitude higher, $51.5 \pm 10.6 \mathrm{~g}$ $\mathrm{N}_{2} \mathrm{O} \mathrm{t}^{-1}\left(4.5 \pm 0.9 \mathrm{~g} \mathrm{~N}_{2} \mathrm{O} \mathrm{GJ}^{-1}\right)$ (Table 2).

From the share of waste burnt in plants with SCR and SNCR $\mathrm{NO}_{\mathrm{x}}$ abatment technology in $2013-74 \%$ and $26 \%$ respectively (ISWA, 2006; BAFU, 2012 ) - an average $\mathrm{N}_{2} \mathrm{O}$ emission factor for waste incineration in Switzerland of $16.4 \mathrm{~g} \mathrm{~N}_{2} \mathrm{O} \mathrm{t}^{-1}\left(1.4 \mathrm{~g} \mathrm{~N}_{2} \mathrm{O} \mathrm{GJ}^{-1}\right)$ can be estimated. This value is almost 10 times lower than the emission factor $\left(120 \mathrm{~g} \mathrm{~N}_{2} \mathrm{O} \mathrm{t}^{-1}\right)$ used in the 2013 Swiss GHG Inventory Report (FOEN, 2013) and close to the emission factors of 12.6 and $12.2 \mathrm{~g} \mathrm{~N}_{2} \mathrm{O} \mathrm{t}^{-1}$ used by Denmark and Austria (DCE, 2013; 
Anderl et al., 2013). The measured emission factors are lower than those used by most European countries in their GHG Inventory reports (Table 2); for example, the Netherlands reports $100 \mathrm{~g} \mathrm{~N}_{2} \mathrm{O} \mathrm{t}^{-1}$ and $20 \mathrm{~g} \mathrm{~N}_{2} \mathrm{O} \mathrm{t}^{-1}$ for SNCR and SCR plants respectively, and the IPCC default value is $50 \mathrm{~g} \mathrm{~N}_{2} \mathrm{O}$ $\mathrm{t}^{-1}$, higher even than the SNCR emission factor found in this study (Coenen et al., 2013; IPCC, 2006). The highest reported emission factor for a continuously operated grate firing WTE plant is used by Canada, where the value of $148 \mathrm{~g} \mathrm{~N}_{2} \mathrm{O} \mathrm{t}^{-1}$ is obtained as the center of the recommended range for five stoker facilities (26-270 $\mathrm{g} \mathrm{N}_{2} \mathrm{O} \mathrm{t}^{-1}$ ) from IPCC (1997). Emissions may, however, be higher for other incineration technologies (eg. fluidized bed), management practices (batch type or open burning) and waste types (eg. sewage sludge) or in developing countries, where incineration and $\mathrm{NO}_{\mathrm{x}}$ removal conditions are less optimal (IPCC, 2006; Hoornweg and Bhada-Tata, 2012).

The contribution of $\mathrm{N}_{2} \mathrm{O}$ emissions to the total GHG footprint of WTE plants can be calculated considering $\mathrm{CO}_{2}$ emissions from WTE of $1271 \mathrm{~kg}$ $\mathrm{CO}_{2} \mathrm{t}^{-1}$ (EMIS, 2013), a GWP of 298 for $\mathrm{N}_{2} \mathrm{O}$ (100 year; Forster et al. $(2007)$ ), and an average fossil $\mathrm{CO}_{2}$ contribution of $48 \pm 4 \%$ in Switzerland $\left(f_{\mathrm{CO}_{2} \text {,fossil }}\right.$; Mohn et al. $\left.(2008,2012 \mathrm{a})\right)$ :

$$
\mathrm{GHG}_{\mathrm{N}_{2} \mathrm{O}: \mathrm{CO}_{2}}=\mathrm{EF}_{\mathrm{N}_{2} \mathrm{O}} \times \mathrm{GWP}_{\mathrm{N}_{2} \mathrm{O}} /\left(\mathrm{EF}_{\mathrm{CO}_{2}} \times f_{\mathrm{CO}_{2}, \text { fossil }}\right)
$$

$\mathrm{N}_{2} \mathrm{O}$ emissions from waste incineration in Switzerland account for $<0.3 \%$ of total GHG emissions from plants with SCR and $\approx 2.5 \%$ of GHG emissions from plants with SNCR - compared to $5.9 \%$ with the previously reported Swiss emission factor of $120 \mathrm{~g} \mathrm{~N}_{2} \mathrm{O} \mathrm{t}^{-1}$. The previous Swiss emission factor, and possibly the emission factors used in a number of other countries with similar incineration technology, quite strongly overestimates the contribution of $\mathrm{N}_{2} \mathrm{O}$ to total GHG emissions from WTE.

\section{2. $\mathrm{N}_{2} \mathrm{O}$ isotopic composition}

The $\mathrm{N}_{2} \mathrm{O}$ isotopic composition was measured at the two plants with SNCR $\mathrm{NO}_{\mathrm{x}}$ removal, plants $\mathrm{D}$ and $\mathrm{E}$. The isotopic composition was corrected for $325 \mathrm{ppb}$ background tropospheric $\mathrm{N}_{2} \mathrm{O}$ with $\delta^{15} \mathrm{~N}^{\text {bulk }}=6.72 \pm 0.12 \%$ and SP $=18.7 \pm 2.2 \%$ (Toyoda and Yoshida, 1999; Toyoda et al., 2013) according to:

$$
\left[\mathrm{N}_{2} \mathrm{O}\right]_{\text {measured }} \delta_{\text {measured }}=\left[\mathrm{N}_{2} \mathrm{O}\right]_{\text {source }} \delta_{\text {source }}+\left[\mathrm{N}_{2} \mathrm{O}\right]_{\text {background }} \delta_{\text {background }}
$$


The raw and corrected values are shown in Table 3. The $\delta^{15} \mathrm{~N}^{\alpha}, \delta^{15} \mathrm{~N}^{\beta}$ and $\delta^{15} \mathrm{~N}^{\text {bulk }}$ values are significantly different between the two incineration plants $(\mathrm{p}<0.001)$, whereas the site preference value is the same for both plants ( $p>0.5$; for both raw and corrected data). This can be explained by the fact that $\delta^{15} \mathrm{~N}$ values likely reflect differences in incineration and SNCR operating conditions, particularly temperature and SNCR efficiency. In contrast, these effects cancel each other out when calculating the difference between $\delta^{15} \mathrm{~N}^{\alpha}$ and $\delta^{15} \mathrm{~N}^{\beta}$ (site preference). Therefore, the site preference values are not affected by the operating conditions, but reflect the identity of the formation pathways in both SNCR plants. SP of $17.6 \pm 0.8 \%$ (corrected) could therefore be used as an indicator for $\mathrm{N}_{2} \mathrm{O}$ emissions from WTE with SNCR. $\mathrm{N}_{2} \mathrm{O}$ emissions from incinerators with $\mathrm{SCR} \mathrm{NO}_{\mathrm{x}}$ reduction are negligible compared to SNCR plants, and are primarily composed of ambient $\mathrm{N}_{2} \mathrm{O}$. Additionally, $\mathrm{N}_{2} \mathrm{O}$ formation reactions in SCR catalysts might be more complex, with branching between pathways depending on temperature, catalyst age and other conditions, and therefore the SP value of $\mathrm{N}_{2} \mathrm{O}$ from SCR may be less reproducible between plants (Kondratenko et al., 2008). Thus constraining the source signature of $\mathrm{N}_{2} \mathrm{O}$ emissions from WTE with SCR technology through atmospheric isotopic measurements is both less important and more difficult.

This study presents, to our knowledge, the first measurements of $\mathrm{N}_{2} \mathrm{O}$ isotopic composition from a WTE plant. $\mathrm{N}_{2} \mathrm{O}$ formed in coal combustion was measured to be initially enriched in ${ }^{15} \mathrm{~N}$ compared to the coal with an SP of 18-19\%; subsequent decomposition in the furnace then reduces the SP and $\delta^{15} \mathrm{~N}$ of the final emitted $\mathrm{N}_{2} \mathrm{O}$ (Ogawa and Yoshida, 2005a). $\mathrm{N}_{2} \mathrm{O}$ in coal combustion furnaces is formed from $\mathrm{SNCR}_{\mathrm{deNO}}$, as in the WTE plants considered in this study, which explains the good agreement in SP values. $\mathrm{N}_{2} \mathrm{O}$ formed from agricultural residue incineration with no deNO $\mathrm{N}_{\mathrm{x}}$, in contrast, has a low SP $\left(<6 \%\right.$ ) (Ogawa and Yoshida, 2005b), as does automobile $\mathrm{N}_{2} \mathrm{O}$ before catalytic conversion ( $\mathrm{SP}=4.2 \pm 0.8 \%$ ) (Toyoda et al., 2008). Reduction of $\mathrm{N}_{2} \mathrm{O}$ in the catalytic converter increases the SP $(\epsilon=-19.5 \pm 0.6 \%)$ of the remaining $\mathrm{N}_{2} \mathrm{O}$, thus the $\mathrm{N}_{2} \mathrm{O}$ downstream of the catalytic converter has a more variable isotopic composition (Toyoda et al., 2008). The consistency of $\mathrm{SP}$ values measured in this study for all the samples at each of the two WTE plants, and between the two plants, therefore suggests that $\mathrm{N}_{2} \mathrm{O}$ reduction or decomposition is negligible in the WTE SNCR. The good agreement between WTE and coal combustion $\mathrm{N}_{2} \mathrm{O}$, both produced from SNCR, shows that an SP of $17-19 \%$ may be characteristic for SNCR. To confirm this additional 
measurements are required in the future.

\subsection{Methane emissions}

Methane mixing ratios for weekly samples throughout the measurement period are shown in Figure 2. Annual average mixing ratios measured at each plant are shown in Table 1. All except one of the flue gas samples had methane mole fractions below ambient $(1.8 \mathrm{ppm})$ and only around one third of all flue gas samples had methane mixing ratios above the detection limit of $0.3 \mathrm{ppm}$. There was no significant difference between plants with SCR and SNCR deNO technology.

Methane emission factors were estimated from the ratio of $\mathrm{CH}_{4}$ to $\mathrm{CO}_{2}$ emissions following Eq. 2 (EMIS, 2013). The $\mathrm{CH}_{4}$ mixing ratios, and therefore the emission factors for plants $\mathrm{A}, \mathrm{B}$ and $\mathrm{E}$, were below the LOD (equivalent to $<1.4 \mathrm{~g} \mathrm{CH}_{4} \mathrm{t}^{-1}$ ), while for $\mathrm{C}$ and $\mathrm{D}$ the emission factors were $2.1 \pm 3.3$ and $2.5 \pm 5.6 \mathrm{~g} \mathrm{CH}_{4} \mathrm{t}^{-1}$ respectively. Our results are consistent with expectations that high incinerator temperatures result in efficient combustion and negligible methane emissions from WTE (IPCC, 2006; Bogner et al., 2008). The results are also in good agreement with emission factors reported by other countries, for example Japan, where emissions of $2.7 \mathrm{~g} \mathrm{CH}_{4} \mathrm{t}^{-1}$ are presumed for continuous operation (GIO, 2013). Following Eq. 3 and considering a GWP for $\mathrm{CH}_{4}$ of 25 (Forster et al., 2007), $\mathrm{CH}_{4}$ contributes a maximum of $0.01 \pm 0.02 \%$ of greenhouse gas emission from waste incineration compared to $\mathrm{CO}_{2}$.

\section{Conclusions}

$\mathrm{N}_{2} \mathrm{O}$ emissions were measured to be around an order of magnitude higher from WTE plants with SNCR $\mathrm{NO}_{x}$ abatement compared to $\mathrm{SCR} \mathrm{NO}_{\mathrm{x}}$ abatement. However, even the average emission factor for SNCR facilities $(51.5 \pm 10.6$ $\mathrm{g} \mathrm{N}_{2} \mathrm{O} \mathrm{t}^{-1}$ ) was almost three times lower than the emission factor previously used in the Swiss GHG inventory (120 $\mathrm{g} \mathrm{N}_{2} \mathrm{O} \mathrm{t}^{-1}$; FOEN (2013)). An average Swiss emission factor of $16.4 \mathrm{~g} \mathrm{~N}_{2} \mathrm{O} \mathrm{t}^{-1}$ was found considering $74 \%$ of Swiss waste by weight is burnt in facilities with SCR, and the remaining $26 \%$ in plants with SNCR, which is significantly lower than the IPCC default value of $50 \mathrm{~g} \mathrm{~N}_{2} \mathrm{O} \mathrm{t}^{-1}$ for WTE. This may be due to wider use of SNCR in many countries and suboptimal $\mathrm{NO}_{\mathrm{x}}$ abatement conditions, as well as alternative plant technologies such as fluidized bed incineration, or semi-continuous or batch operation, resulting in higher $\mathrm{N}_{2} \mathrm{O}$ emissions. 
The average isotopic $\mathrm{SP}$ of $\mathrm{N}_{2} \mathrm{O}$ in flue gas measured in the two plants with SNCR was $17.6 \pm 0.8 \%$. This is in relatively good agreement with $\mathrm{N}_{2} \mathrm{O}$ released from coal combustion with SNCR (18-19\%;; Ogawa and Yoshida (2005a)). Consistent measurements over an entire year between the two plants suggests that reduction or decomposition of $\mathrm{N}_{2} \mathrm{O}$ after formation is negligible. SP of 17-19\% may therefore be a characteristic $\mathrm{SP}$ value for $\mathrm{N}_{2} \mathrm{O}$ production from SNCR.

$\mathrm{CH}_{4}$ measurements at the five WTE facilities showed that emissions are negligible, as expected due to high incineration temperatures and efficient combustion (Bogner et al., 2008). A maximum $\mathrm{CH}_{4}$ emission factor of $2.5 \pm 5.6 \mathrm{~g} \mathrm{CH}_{4} \mathrm{t}^{-1}$ was found, which means $\mathrm{CH}_{4}$ contributes $<0.01 \%$ of total GHG emissions from WTE.

\section{Acknowledgements}

The authors thank the Federal Office for the Environment (FOEN) for financial support. Eliza Harris was supported by the European Unions Seventh Framework Programme for research, technological development and demonstration under grant agreement no. 2010-267161. We would like to thank Barbora Durciova for support in gas sampling and analysis. We are grateful to the operators and the contact persons of the WTE plants for their help during the field campaign. 


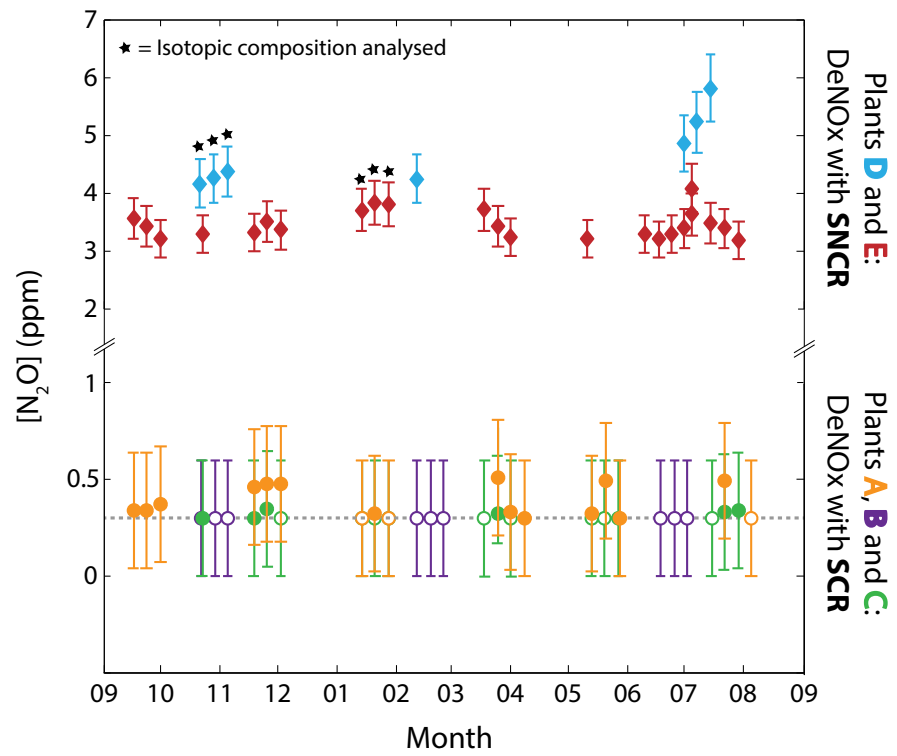

Figure 1: Flue gas $\mathrm{N}_{2} \mathrm{O}$ mixing ratios measured at five waste incineration plants between September 2010 and August 2011. Plants A, B and C employ $\mathrm{NO}_{\mathrm{x}}$ abatement with selective catalytic reduction (SCR) while plants $\mathrm{D}$ and $\mathrm{E}$ reduce $\mathrm{NO}_{\mathrm{x}}$ emissions with selective non-catalytic reduction (SNCR). The limit of detection (LOD) is shown as a dashed grey line; points falling below the LOD are set to the LOD and shown as unfilled circles (ie. 'worst case' scenario). Note the break and scale change in the y-axis. 


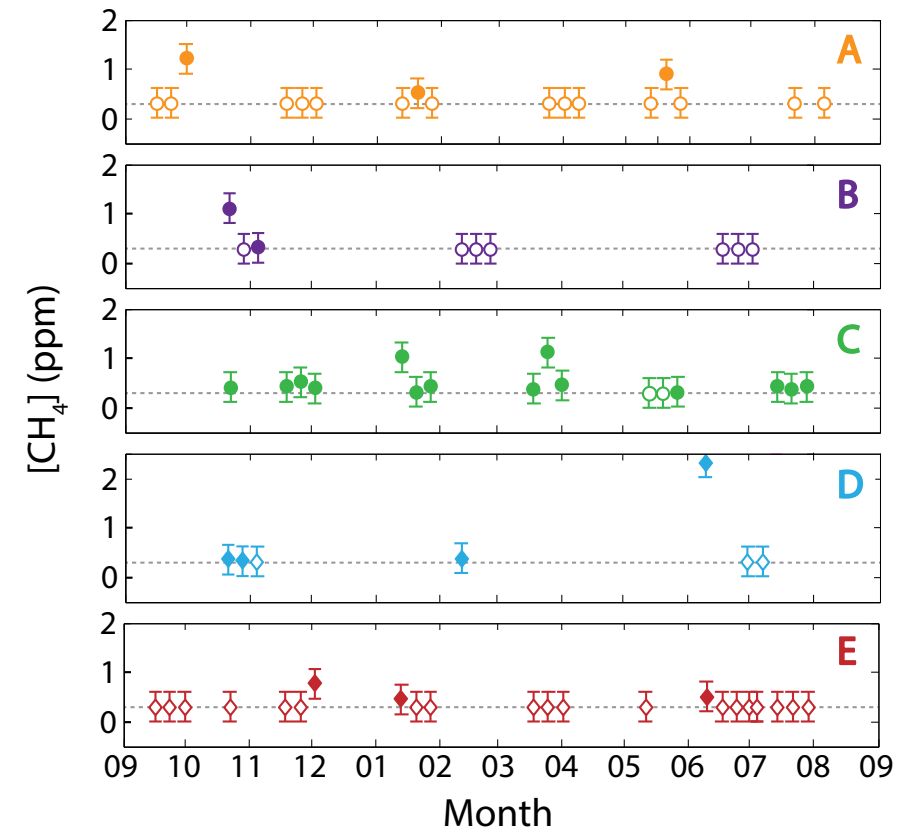

Figure 2: Flue gas methane mixing ratios measured at five waste incineration plants (labelled A-E) between September 2010 and August 2011. The limit of detection (LOD) is shown as a dashed grey line; points falling below the LOD are set to the LOD and shown as unfilled circles (ie. 'worst case' scenario). 
Table 1: Annual average $\mathrm{CH}_{4}, \mathrm{~N}_{2} \mathrm{O}$ and $\mathrm{CO}_{2}$ mixing ratios measured in flue gas at five Swiss waste incineration plants between September 2010 and August 2011. $n=$ number of bag samples taken. SCR = Selective Catalytic Reduction; SNCR = Selective nonCatalytic Reduction. Average values for each deNO $\mathrm{x}_{\mathrm{x}}$ technology are also shown - these values represent a 'worst case' scenario as all values less than the LOD were set to the LOD to calculate the average.

\begin{tabular}{ccrrrc} 
Plant & $\begin{array}{c}\text { deNO } \\
\text { technology }\end{array}$ & $\boldsymbol{n}$ & \multicolumn{1}{c}{$\begin{array}{c}\mathbf{C H}_{4} \\
(\mathrm{ppm})\end{array}$} & \multicolumn{1}{c}{$\begin{array}{c}\mathbf{N}_{2} \mathbf{O} \\
(\mathrm{ppm})\end{array}$} & $\begin{array}{c}\mathbf{C O}_{2} \\
(\%)\end{array}$ \\
\hline $\mathrm{A}$ & $\mathrm{SCR}$ & 17 & $<0.3 \pm 0.3$ & $0.35 \pm 0.3$ & $9.5 \pm 1.0$ \\
$\mathrm{~B}$ & $\mathrm{SCR}$ & 9 & $<0.3 \pm 0.3$ & $<0.3 \pm 0.3$ & $9.7 \pm 1.0$ \\
$\mathrm{C}$ & $\mathrm{SCR}$ & 16 & $0.46 \pm 0.5$ & $<0.3 \pm 0.3$ & $9.9 \pm 1.0$ \\
$\mathrm{D}$ & $\mathrm{SNCR}$ & 7 & $0.5 \pm 1.4$ & $4.7 \pm 1.2$ & $9.9 \pm 1.0$ \\
$\mathrm{E}$ & $\mathrm{SNCR}$ & 21 & $<0.3 \pm 0.3$ & $3.4 \pm 0.4$ & $9.9 \pm 1.0$ \\
\hline Mean, SCR & & 42 & $0.4 \pm 0.1$ & $0.3 \pm 0.1$ & $9.7 \pm 0.6$ \\
Mean, SNCR & & 28 & $0.4 \pm 0.2$ & $4.1 \pm 0.9$ & $9.9 \pm 0.7$ \\
\hline
\end{tabular}


Table 2: Emission factors for $\mathrm{N}_{2} \mathrm{O}$ in $\mathrm{g} \mathrm{N}_{2} \mathrm{O}$ tonne $\mathrm{t}^{-1}$ of wet waste (abbreviated as $\mathrm{t}^{-1}$ ) as well as $\mathrm{kg} \mathrm{CO}_{2}$ equivalent from $\mathrm{N}_{2} \mathrm{O}\left(\mathrm{kg} \mathrm{CO}_{2}\right.$-eq $\left.\mathrm{t}^{-1}\right)$ from five Swiss waste incineration plants measured between September 2010 and August 2011. SCR = Selective Catalytic Reduction; SNCR = Selective non-Catalytic Reduction. Errors are one standard deviation calculated by error propogation from uncertainties in $\mathrm{N}_{2} \mathrm{O}$ and $\mathrm{CO}_{2}$ mixing ratio measurements, as shown in Table 1. Averages represent a 'worst case' scenario as all values less than the LOD were set to the LOD for the calculation. Emission factors for other continous grate firing incineration plants from previous studies and assessments are shown for comparison: 1) Blain et al. (2013), 2) FOEN (2000), 3) Coenen et al. (2013), 4) IPCC (2006), 5) GIO (2013), 6) Webb et al. (2013), 7) Rosland and Kolshus (2013), 8) DCE (2013); Nielsen et al. (2010), 9) Anderl et al. (2013), 10) Johnke (2003).

\begin{tabular}{|c|c|c|c|}
\hline Plant & $\begin{array}{c}\operatorname{deNO}_{\mathrm{x}} \\
\text { technology }\end{array}$ & $\begin{array}{c}\mathbf{E F} \\
\left(\mathrm{g} \mathrm{N}_{2} \mathrm{O} \mathrm{t}^{-1}\right)\end{array}$ & $\begin{array}{c}\mathbf{E F} \\
\left(\mathrm{kg} \mathrm{CO}_{2}-\mathrm{eq} \mathrm{t}^{-1}\right)\end{array}$ \\
\hline $\mathrm{A}$ & SCR & $5 \pm 4$ & $1.5 \pm 2.2$ \\
\hline $\mathrm{B}$ & SCR & $<4.0 \pm 3.6$ & $<1.2 \pm 1.1$ \\
\hline $\mathrm{C}$ & SCR & $<4.0 \pm 3.6$ & $<1.2 \pm 1.1$ \\
\hline $\mathrm{D}$ & SNCR & $59 \pm 18$ & $17.6 \pm 4.5$ \\
\hline $\mathrm{E}$ & SNCR & $44 \pm 8$ & $13.1 \pm 2.8$ \\
\hline \multicolumn{2}{|c|}{ Mean, $S C R$} & $4.3 \pm 4.0$ & $1.3 \pm 1.1$ \\
\hline \multicolumn{2}{|c|}{ Mean, SNCR } & $51.5 \pm 10.6$ & $15.3 \pm 2.8$ \\
\hline \multicolumn{2}{|c|}{ Canada $^{1}$} & 148 & 44 \\
\hline \multicolumn{2}{|c|}{ Switzerland ${ }^{2}$} & 120 & 36 \\
\hline \multicolumn{2}{|c|}{ Netherlands, with SNCR ${ }^{3}$} & 100 & 30 \\
\hline \multicolumn{2}{|c|}{ IPCC Default $^{4}$} & 50 & 15 \\
\hline \multicolumn{2}{|c|}{$\operatorname{Japan}^{5}$} & 38 & 11 \\
\hline \multicolumn{2}{|l|}{$\mathrm{UK}^{6}$} & 38 & 11 \\
\hline \multicolumn{2}{|l|}{ Norway $^{7}$} & 35 & 10 \\
\hline \multicolumn{2}{|c|}{ Netherlands, without SNCR ${ }^{3}$} & 20 & 6 \\
\hline \multicolumn{2}{|c|}{ Denmark $^{8}$} & 12.6 & 3.8 \\
\hline \multicolumn{2}{|c|}{ Austria $^{9}$} & 12.2 & 3.6 \\
\hline \multicolumn{2}{|c|}{ Germany $^{10}$} & 8 & 2.4 \\
\hline
\end{tabular}


Table 3: Average isotopic composition of $\mathrm{N}_{2} \mathrm{O}$ measured in the offgas of two waste incineration plants with SNCR deNO ${ }_{x}$ technology (plants D and E). Raw measured data and results corrected for background tropospheric $\mathrm{N}_{2} \mathrm{O}$ are shown for both plants. An overall mean is shown only for site preference; all other values are significantly different between the two plants. Error is one standard deviation.

\begin{tabular}{|c|c|c|c|c|c|}
\hline Plant & Date & $\begin{array}{c}\delta^{15} \mathbf{N}^{\alpha} \\
(\% 0) \\
\end{array}$ & $\begin{array}{c}\delta^{15} \mathbf{N}^{\beta} \\
(\% 0)\end{array}$ & $\begin{array}{c}\delta^{15} \mathbf{N}^{\text {bulk }} \\
(\% 0)\end{array}$ & $\begin{array}{c}\text { Site preference } \\
(\% 0)\end{array}$ \\
\hline \multicolumn{6}{|c|}{ Raw data } \\
\hline $\mathrm{D}$ & $18.10 .10-8.11 .10$ & $10.4 \pm 0.4$ & $-7.2 \pm 1.1$ & $1.6 \pm 0.7$ & $17.6 \pm 0.8$ \\
\hline \multirow[t]{2}{*}{$\mathrm{E}$} & $10.01 .11-31.01 .11$ & $12.8 \pm 0.1$ & $-5.0 \pm 0.3$ & $3.9 \pm 0.1$ & $17.8 \pm 0.4$ \\
\hline & & & & Mean & $17.7 \pm 0.6$ \\
\hline \multicolumn{6}{|c|}{ Corrected data } \\
\hline $\mathrm{D}$ & $18.10 .10-8.11 .10$ & $10.0 \pm 0.6$ & $-7.6 \pm 1.4$ & $1.2 \pm 0.8$ & $17.5 \pm 0.8$ \\
\hline \multirow[t]{2}{*}{$\mathrm{E}$} & $10.01 .11-31.01 .11$ & $12.5 \pm 0.3$ & $-5.2 \pm 0.5$ & $3.6 \pm 0.1$ & $17.7 \pm 0.4$ \\
\hline & & & & Mean & $17.6 \pm 0.8$ \\
\hline
\end{tabular}


Anderl, M., Freudenschuss, A., Friedrich, A., Haider, S., Jobstmann, H., Koether, T., Kriech, M., Lampert, C., Pazdernik, K., Poupa, S., Schindlbacher, S., Stranner, G., Schwaiger, E., Seuss, K., Weiss, P., Wieser, M., Zechmeister, A., Zethner, G., 2013. Austria's National Inventory Report 2013 - Submission under the United Nations Framework Convention on Climate Change and the Kyoto Protocol. Tech. rep., Umweltbundesamt, Vienna.

URL http://www . umweltbundesamt.at/fileadmin/site/publikationen/REP0416.pdf

Astrup, T., Mø ller, J., Fruergaard, T., Nov. 2009. Incineration and cocombustion of waste: accounting of greenhouse gases and global warming contributions. Waste management \& research : the journal of the International Solid Wastes and Public Cleansing Association, ISWA 27 (8), 789-99.

URL http://www.ncbi.nlm.nih.gov/pubmed/19748939

BAFU, 2004. Abfallstatistiken: KVA-Ausruestung. Tech. rep., Bundesamt für Umwelt.

BAFU, 2012. Brennbare Abfälle in Kehrichtverbrennungsanlagen (KVA). Tech. rep., Bundesamt für Umwelt. URL http://www . bafu .admin. ch/abfall/01517/01519/12949/index.html?lang=de

BFE/BAFU, 2013. Einheitliche Heizwert- und Energiekennzahlenberechnung der Schweizer KVA nach europäischem Standardverfahren. Tech. rep., Bundesamt für Umwelt/Bundesamt für Energie.

URL www. bfe .admin. ch/php/modules/publikationen/stream.php?extlang=de\&name=de_14!

Blain, D., Matin, A., McGovern, M., McKibbon, S., Moore, D., Neitzert, F., Pratt, L., Smyth, S., 2013. Greenhouse gas sources and sinks in Canada: National Inventory Report. Tech. rep., Environment Canada.

Bogner, J., Ahmed, M. A., Diaz, C., Faaij, A., Gao, Q., Hashimoto, S., Mareckova, K., Pipatti, R., Zhang, T., 2007. Waste Management. In: Davidson, O. R., Bosch, P. R., Dave, R., Meyer, L. A. (Eds.), Climate Change 2007: Mitigation. Contribution of working group III to the Fourth Assessment Report of the Intergovernmental Panel on Climate Change. Cambridge University Press, Cambridge, pp. 585-618. 
Bogner, J., Pipatti, R., Hashimoto, S., Diaz, C., Mareckova, K., Diaz, L., Kjeldsen, P., Monni, S., Faaij, a., Sutamihardja, R., Gregory, R., Feb. 2008. Mitigation of global greenhouse gas emissions from waste: conclusions and strategies from the Intergovernmental Panel on Climate Change (IPCC) Fourth Assessment Report. Working Group III (Mitigation). Waste Management \& Research 26 (1), 11-32.

URL http://wmr.sagepub.com/cgi/doi/10.1177/0734242X07088433

Coenen, P. W. H. G., van der Maas, C. W. M., Zijlema, P. J., Arets, E. J. M. M., Baas, K., van den Berghe, A. C. W. M., te Biesebeek, J. D., Brandt, A. T., Geilenkirchen, G., van der Hoek, K. W., te Molder, R., Dröge, R., Montfoort, J. A., Peek, C. J., Vonk, J., 2013. Greenhouse gas emission in The Netherlands, 1990-2011. Tech. rep., National Institute for Public Health and the Environment, Bilthoven.

DCE, 2013. Denmark's National Inventory Report 2013. Tech. Rep. 56, Danish Centre for Environment and Energy, Aarhus University.

EMIS, 2013. Municipal Waste Incineration Plants. Bern.

FOEN, 2000. Emissionsfaktoren für stationäre Quellen. Tech. rep., Federal Office for the Environment (FOEN), Bern.

FOEN, 2013. Switzerland's Greenhouse Gas Inventory, 1990-2011. Tech. Rep. April, Federal Office for the Environment (FOEN), Bern.

FOEN, 2014. Waste.

URL http://www . bafu .admin. ch/abfall/index.html?lang=en

Forster, P. M., Ramaswamy, V., Artaxo, P., Berntsen, T. K., Betts, R., Fahey, D. W., Haywood, J., Lean, J., Lowe, D. C., Myrhe, G., Nganga, J., Prinn, R., Raga, G., Schulz, M., Van Dorland, R., 2007. Changes in Atmospheric Constituents and in Radiative Forcing. In: Climate Change 2007: The physical science basis. Contribution of the working group I to the Fourth Assessment Report of the Intergovernmental Panel on Climate Change.

Fukushima, Y., Liu, P.-W. G., Tsai, J.-H., Feng Lee, C., Tseng, T. K., Jan. 2008. Preliminary Investigation of Greenhouse Gas Emissions from the Environmental Sector in Taiwan. Journal of the Air \& Waste Management 
Association 58 (1), 85-94.

URL http://www . tandfonline.com/doi/abs/10.3155/1047-3289.58.1.85

GIO, 2013. National Greenhouse Gas Inventory Report of JAPAN. Tech. rep., Greenhouse Gas Inventory Office of Japan (GIO).

Grosso, M., Diiar, M., Rigamonti, L., 2009. Experimental assessment of N2O emissions from waste incineration: the role of NOx control technology. In: Vieira, J. M. P., Ramisio, P. J., Silveira, A. I. E. (Eds.), Turning waste into ideas. ISWA/APESB 2009 World Congress: Book of Abstracts. pp. $1-10$.

Harris, E., Nelson, D. D., Olszewski, W., Zahniser, M., Potter, K. E., McManus, B. J., Whitehill, A., Prinn, R. G., Ono, S., Feb. 2014. Development of a spectroscopic technique for continuous online monitoring of oxygen and site-specific nitrogen isotopic composition of atmospheric nitrous oxide. Analytical chemistry 86 (3), 1726-34.

URL http://www.ncbi.nlm.nih.gov/pubmed/24328290

Hoornweg, D., Bhada-Tata, P., 2012. What a Waste: A Global Review of Solid Waste Management. Tech. rep., The World Bank.

IPCC, 1997. Chapter 6: Waste. In: Revised 1996 IPCC Guidelines for National Greenhouse Gas Inventories: Reference Manual. p. 32.

URL http://www .ipcc-nggip.iges.or.jp/public/gl/invs6.html

IPCC, 2006. 2006 IPCC Guidelines for National Greenhouse Gas Inventories: Volume 5 - Waste. IGES, Japan.

ISWA, 2006. Energy from Waste: State-of-the-Art Report. No. August. International Solid Waste Association, Working Group on Thermal Treatment of Waste.

Johnke, B., 2003. Emission reporting/Preparation of the Inventory for the year 2002 (In German: Emissionsberichterstattung / Inventarerstellung fuer das Jahr 2002 (as cited in IPCC 2006). Tech. rep., Umweltbundesamt, Berlin.

Kondratenko, V., Bentrup, U., Richter, M., Hansen, T., Kondratenko, E., Dec. 2008. Mechanistic aspects of $\mathrm{N} 2 \mathrm{O}$ and $\mathrm{N} 2$ formation in NO reduction by $\mathrm{NH} 3$ over Ag/Al2O3: The effect of $\mathrm{O} 2$ and H2. Applied Catalysis B: 
Environmental 84 (3-4), 497-504.

URL http://linkinghub.elsevier.com/retrieve/pii/S0926337308001756

Köster, J. R., Well, R., Tuzson, B., Bol, R., Dittert, K., Giesemann, A., Emmenegger, L., Manninen, A., Cárdenas, L., Mohn, J., Jan. 2013. Novel laser spectroscopic technique for continuous analysis of N2O isotopomersapplication and intercomparison with isotope ratio mass spectrometry. Rapid communications in mass spectrometry : RCM 27 (1), 216-22.

URL http://www.ncbi.nlm.nih.gov/pubmed/23239336

Mohn, J., Guggenheim, C., Tuzson, B., Vollmer, M. K., Toyoda, S., Yoshida, N., Emmenegger, L., May 2010. A liquid nitrogen-free preconcentration unit for measurements of ambient $\mathrm{N} 2 \mathrm{O}$ isotopomers by QCLAS. Atmospheric Measurement Techniques 3 (3), 609-618.

Mohn, J., Szidat, S., Fellner, J., Rechberger, H., Quartier, R., Buchmann, B., Emmenegger, L., Sep. 2008. Determination of biogenic and fossil CO2 emitted by waste incineration based on $14 \mathrm{CO} 2$ and mass balances. Bioresource technology 99 (14), 6471-9.

URL http://www.ncbi.nlm.nih.gov/pubmed/18164616

Mohn, J., Szidat, S., Zeyer, K., Emmenegger, L., Aug. 2012a. Fossil and biogenic $\mathrm{CO} 2$ from waste incineration based on a yearlong radiocarbon study. Waste management 32 (8), 1516-20.

URL http://www.ncbi.nlm.nih.gov/pubmed/22542859

Mohn, J., Tuzson, B., Manninen, A., Yoshida, N., Toyoda, S., Brand, W. A., Emmenegger, L., 2012b. Site selective real-time measurements of atmospheric $\mathrm{N} 2 \mathrm{O}$ isotopomers by laser spectroscopy. Atmospheric Measurement Techniques 5, 1601-1609.

Mohn, J., Wolf, B., Toyoda, S., Li, C.-T., Liang, M.-C., Brüggemann, N., Wissel, H., Steiker, A. E., Dyckman, J., Szwec, L., Ostrom, N. E., Casciotti, K., Forbes, M., Giesemann, A., Well, R., Doucett, R. R., Yarnes, C. T., Ridley, A. R., Kaiser, J., Yoshida, N., 2014. Interlaboratory assessment of nitrous oxide isotopomer analysis by isotope ratio mass spectrometry and laser spectroscopy: Current status and perspectives. Rapid Communications In Mass Spectrometry 28, 1995-2007. 
Moller, J., Munk, B., Crillesen, K., Christensen, T. H., Jun. 2011. Life cycle assessment of selective non-catalytic reduction (SNCR) of nitrous oxides in a full-scale municipal solid waste incinerator. Waste management (New York, N.Y.) 31 (6), 1184-93.

URL http://www.ncbi.nlm.nih.gov/pubmed/21277187

Nielsen, M., Nielsen, O.-K., Plejdrup, M., Hjelgaard, K., 2010. Danish emission inventories for stationary combustion plants: Inventories until 2008. NERI Technical Report no. 795, 240.

NIOSH, 2000. Method 3800: Organic and Inorganic Gases by Extractive FTIR Spectrometry. In: Manual of Analytical Methods, 4th Edition. National Institute for Occupational Safety and Health, pp. 1-47.

Ogawa, M., Yoshida, N., Nov. 2005a. Intramolecular distribution of stable nitrogen and oxygen isotopes of nitrous oxide emitted during coal combustion. Chemosphere 61 (6), 877-87.

URL http://www.ncbi.nlm.nih.gov/pubmed/15993467

Ogawa, M., Yoshida, N., Jun. 2005b. Nitrous oxide emission from the burning of agricultural residue. Atmospheric Environment 39 (19), 3421-3429. URL http://linkinghub.elsevier .com/retrieve/pii/S1352231005002086

Park, S., Choi, J.-H., Park, J., Aug. 2011a. The estimation of N2O emissions from municipal solid waste incineration facilities: The Korea case. Waste management 31 (8), 1765-1771.

URL http://www.ncbi.nlm.nih.gov/pubmed/21478007

Park, S., Perez, T., Boering, K. A., Trumbore, S. E., Gil, J., Marquina, S., Tyler, S. C., Jan. 2011b. Can N2O stable isotopes and isotopomers be useful tools to characterize sources and microbial pathways of N2O production and consumption in tropical soils? Global Biogeochemical Cycles 25, GB1001.

Rosland, A., Kolshus, H. H., 2013. Norway's National Inventory Report: Greenhouse Gas Emissions 1990-2011. Tech. rep., Climate and Pollution Agency, Oslo.

Skalska, K., Miller, J. S., Ledakowicz, S., Sep. 2010. Trends in NOx abatement: A review. Science of The Total Environment 408 (19), 3976-3989. URL http://linkinghub.elsevier .com/retrieve/pii/S0048969710005565 
Svoboda, K., Baxter, D., Martinec, J., Feb. 2006. Nitrous oxide emissions from waste incineration. Chemical Papers 60 (1), 78-90. URL http://www . springerlink.com/index/10.2478/s11696-006-0016-x

Toyoda, S., Kuroki, N., Yoshida, N., Ishijima, K., Tohjima, Y., Machida, T., 2013. Decadal time series of tropospheric abundance of $\mathrm{N} 2 \mathrm{O}$ isotopomers and isotopologues in the northern hemisphere obtained by the long-term observation at Hateruma Island, Japan (Running title: Tropospheric N2O isotopomers). Journal of Geophysical Research - Atmospheres 118, 1-13. URL http://dx.doi.org/10.1002/jgrd.50221

Toyoda, S., Suzuki, Y., Hattori, S., Yamada, K., Fujii, A., Yoshida, N., Kouno, R., Murayama, K., Shiomi, H., Feb. 2011. Isotopomer Analysis of Production and Consumption Mechanisms of N2O and CH4 in an Advanced Wastewater Treatment System. Environmental Science \& Technology $45(3), 917-922$.

Toyoda, S., Yamamoto, S.-i., Arai, S., Nara, H., Yoshida, N., Kashiwakura, K., Akiyama, K.-i., 2008. Isotopomeric characterization of N2O produced, consumed, and emitted by automobiles. Rapid Communications In Mass Spectrometry 22, 603-612.

Toyoda, S., Yoshida, N., Oct. 1999. Determination of nitrogen isotopomers of nitrous oxide on a modified isotope ratio mass spectrometer. Analytical Chemistry 71 (20), 4711-4718.

UN, 1992. United Nations Framework Convention on Climate Change.

VDI, 2005. VDI 2469 Part 1 - Gaseous emission measurement: Measurement of nitrous oxide, manual gas chromatographic method. Tech. Rep. February, Düsseldorf.

VDI, 2008. VDI 2466 Part 1 - Gaseous emission measurement: Measurement of methane, manual gas chromatography method. Tech. Rep. October, Düsseldorf.

Wächter, H., Mohn, J., Tuzson, B., Emmenegger, L., Sigrist, M. W., 2008. Determination of N2O isotopomers with quantum cascade laser based absorption spectroscopy. Optics Express 16, 9239-9244. 
550

Webb, N., Broomfield, M., Cardenas, L., MacCarthy, J., Murrells, T., Pang, Y., Passant, N., Thislethwaite, G., Thomson, A., 2013. UK Greenhouse Gas Inventory, 1990 to 2011: Annual Report for Submission under the Framowork Convention on Climate Change. Tech. Rep. April, Department of Energy and Climate Change, Oxfordshire, UK.

Zandaryaa, S., Gavasci, R., Lombardi, F., Fiore, a., 2001. Nitrogen oxides from waste incineration: control by selective non-catalytic reduction. Chemosphere 42 (5-7), 491-7.

URL http://www.ncbi.nlm.nih.gov/pubmed/11219673

Zeyer, K., Mohn, J., 2013. Validierung der Bag Probenahme. Tech. rep., EMPA/Bundesamt für Umwelt (BAFU). 